Volume-IX, Issue-02, July -December, 2014

\title{
Trends in Marketing of New Insurance Schemes and Distribution: An Empirical Study on Indian Life Insurance Sector SUMAN KALYAN CHAUDHURY* SANJAY KANTI DAS**
}

\begin{abstract}
Insurance has been an integral part of financial services system and recognised as a cornerstone of a country's financial health and symbol of progress. Insurance provides for the financial security of citizens and their families. The present paper discusses the role of marketing in insurance distribution of life insurance sector in India as insurance offers a valuable investment advices and serves as an effective step towards both individual and national financial stability. The waves of globalisation have deeply influenced the insurance sector worldwide. Financial globalisation has been strongly supported by globalisation of insurance. With the increase in trade, direct investment and portfolio investment, there has been an ever growing demand for insurance services particularly in the emerging markets. Globalisation of insurance market, as a part of the overall process of liberalisation in emerging and other countries enabled the foreign insurance companies to enter in those countries and benefited both. Triggered by the sound fundamentals in global economy and internationalisation of world markets, several countries turned towards free market regimes in banking and insurance, putting an end to several decadeold state-owned controlled markets. There was a remarkable progress in the Indian insurance industry soon after the acceptance and adaptation of LPG in the year 1991. After 1991, the Indian life insurance industry has geared up in all respects, as well as it has been forced to face a lot of healthy competition from many national as well as international private insurance players. It is also reported by Swiss Re and Munich Re that there would be 20-25 percent growth in life and health insurance market by 2015, particularly in India and China. In this paper an effort is made to study the current status and challenges faced by the life insurance business houses in India.
\end{abstract}

Keywords: Financial globalization, Life insurer, Modern marketing approach, Service marketing, Life Insurance Corporation of India.

\section{INTRODUCTION}

The insurance industry in India seems to have come out of the growth during the economic crisis. Life Insurance companies have witnessed a 70

* Faculty Member, Department of Business Administration, Berhampur University, Berhampur, Odisha, India

** Assistant Professor, Department of Commerce, Lumding College, Lumding, Nagaon, Assam, India 
percent jump in new premium collection during the first five months of the financial year in 2010. The increase comes in a period that saw the insurers trying to push sales ahead of the change in the norms of Unit-Linked Insurance Plans" (Business Standard, 2010). According to the data released by Insurance Regulatory Development Authority (IRDA), insurance companies gathered Rupees 52,749 crore in new business premium in the April-August 2010 period as against Rupees 31,040 crore in the corresponding period last year. During the initial phase of privatisation of Insurance sector in India, the penetration was very low. Indian as well as foreign companies reaped the benefits of a low base and have reported high rate of growth in the last decade. But times have changed now and the way forward is going to be tough. They have to start focusing on the different strategies like customer retention strategy, operational discipline, regulatory developments and opportunities for innovation to drive sustainable growth and profitability.

The Indian Government and policy makers have then found themselves at cross -roads more than once. The large scale fraudulent practices, mismanagement of companies in the first half of the early twentieth century resulted in a major restructuring of the industry and caused the sector to transfer from an unregulated to a highly regulated one. The industry functioned under a monopoly for several decades thereafter. However, other problems surfaced such as limited reach and penetration of enterprise and deteriorating servicing standards etc. In 1991, with the Indian Govt. initiating liberalisation of various other strategic industries, a possible change in strategy was supported by various committees and experts. A milestone was achieved when the nation decided to privatise the industry along with requisite regulations.

The Insurance sector in India has completed a full circle from being an open competitive market to nationalisation and back to a liberalised market again. From 2000, many private players entered into insurance industry with effect of privatisation of insurance sector as per Malhotra Commission's recommendations and formation of Insurance Regulatory Development Authority. The Government having tried various models for the insurance industry such as privatization with negligible regulations (Pre-1956), nationalization (1956- 2000) and having observed sub-optimal performance of the sector, resorted to adapting a hybrid model (Rastogi \& Sarkar, 2008) (Fig- 1) of both these, resulting in privatization of the sector with an efficient regulatory mechanism (Post- 2000). This was initiated with the aim of making the industry competitive so that there are more players offering a greater variety of products over a larger sections of the population. 


\section{FIGURE 1}

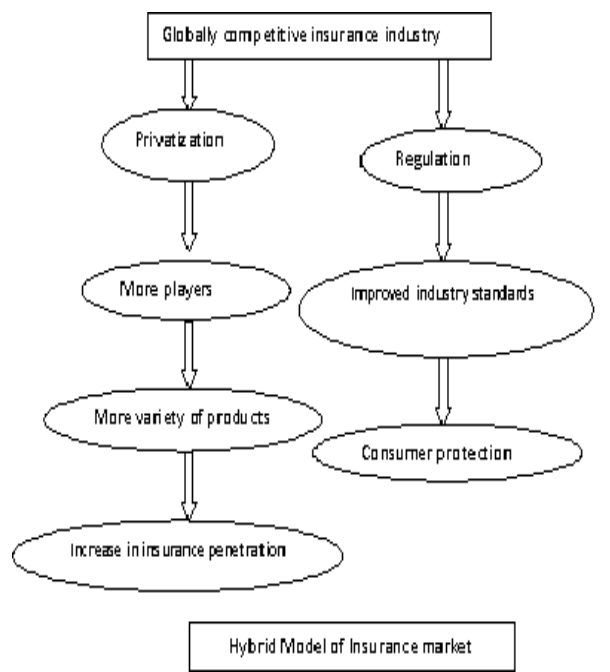

Source: Adapted from Rastogi, Shilpa \& Sarkar, Runa, undated, available at web site of IIM,Kanpur.

With this hybrid model, the industry was thus privatise along with market regulation of players who have the necessary financial strength to withstand the demands of growing and nascent market, the necessity to have 'fit and proper' persons in charge of business, the implementation of a solvency regime that ensures continuous financial stability, and above all, the presence of an adequate number of insurers to provide competition and choice to customers has led to the establishment of a regime committed to an overall development of the market in normal times.

\section{Globalisation of Insurance Market}

Insurance is an integral part of national economy and a strong pillar of financial market. Waves of globalization have deeply influenced the insurance market worldwide. Financial market globalisation has been strongly supported by globalisation of insurance. With the increase in Trade, Direct Investment and Portfolio Investment, there has been an ever growing demand for Insurance services particularly in the emerging markets. Globalisation of insurance market, as a part of the overall process of liberalisation in emerging and other countries enabled the foreign insurance companies to enter in those countries and benefited both. The driving force of insurance market globalisation has been identified by Swiss Re (Sigma No.4/2000) as the 'push factors' and 'Pull Factors'. The Push factors are the motives behind the movement of foreign insurance companies while the pull factors are the motives behind allowing the foreign companies to operate in local market,

(a) Push factors : Insurance Companies move out to emerging markets due to increasing Global Trade, growing Direct Investment, 
potential future growth in Emerging Markets, saturation in industrialized countries and strong growth in emerging countries and expected 'Efficiency Gains through Diversification', Economics of scale etc.

(b) Pull Factors: Emerging markets have strong economic growth and trade, and there are substantial requirements of capital in emerging markets to cover major risks. There are several benefits to the countries allowing foreign insurance companies to operate in their countries which can be broadly classified into Economy related, and Insurance market related.

The various factors which have largely led to the development of insurance sector in its present form can be classified into two groups: Market driven factors and the Regulatory driven factors.

(a) Market Driven Factors: To meet the varying needs of various individuals, the insurance players have a vast range of products in their bouquet. Almost all companies offer the flexibility to customer as per their needs. To reach out to the consumers, the companies in the industry today have widened their distribution channels by approaching prospective customers through agents, brokers and banc assurance. Information Technology has also acts as an alternative channel mostly through internet, for marketing of insurance products.

(b) Regulation Driven Factors: The industry is now opened to private players but have to take license from Insurance Regulatory Development Authority on annual renewal system. Insurance Regulatory Development Authority holds the right to cancel the license of the insurance company if it feels that the insurer fails to conduct its business in a manner prejudicial to the interest of the policy holders.

The Insurance players today are expected to invest the funds judiciously with the combined objectives of liquidity, maximization of yield and safety by conferring to the Authority's guidelines on investments.

The Insurance Regulatory Development Authority has taken a few more initiative to further regulate and develop the sector viz. de-ratification except for auto third party liability, sole authority to underwrite, relatively less number of years of existence for issuance of IPO's etc. Furthermore, the insurance regulator Insurance Regulatory Development Authority has introduced various development initiatives for health insurance segment and ULIP management. There are several other important issues on which Insurance Regulatory Development Authority is working on. Firstly, the convergence of the Indian accounting standards with the IFRS; the settlement of norms (Issuance of IPO's and mergers \& acquisitions), the establishment of a more robust system to collect and disseminate appropriate insurance related data \& several other initiatives. 


\section{OBJECTIVES OF THE STUDY}

The main objective of this paper includes:

a) To study the current trends of Life Insurance sector in India;

b) To evaluate the market share of Life Insurance sector of India in Life insurance business; and

c) To study the trends in the life insurer in India in the globalized environment.

\section{Hypothesis of the Study}

a) Indigenous Indian players Life Insurance sector plays a dominant role in life insurance business in India even after the entry of foreign players; and

b) Indian LIC companies introduced new and innovative marketing strategies to compete with foreign players for their existence

\section{RESEARCH METHODOLOGY}

The research methodology of this study is related to evolutionary research method. Basically, secondary data are used for the study. The secondary data consisted of published annual reports for the concerned years of Life Insurance Corporation of India, website of LIC, website of IRDA, Journal, Magazines of LIC of India, reference books, etc. Figures related to insurance companies are taken from the all-annual reports of the Insurance Regulatory and Development Authority. These were compiled, tabulated and analyzed.

\section{REVIEW OF LITERATURE}

Literature on the performance of life insurance business in India and abroad is enriched. A lot of evaluation studies, comparative studies and empirical studies were conduced during years on the functioning insurance business. Peter, 1999 admitted that by "providing financial protection against the major eighteenth and nineteenth century risk of dying too soon, life insurance became the biggest financial industry of that century. Providing financial protection against the new risk of not dying soon enough may well become that next century's major and most profitable financial industry”.

Rao, 2000 opined, “1999-2000 were landmark years in the history of Indian insurance industry. The year 2007 is going to be another watershed for the industry. Detariffication from first January 2007 will totally change the complexion of the non-life industry. Financial inclusion is being emphasised in various forums. The insurance industry will have to play a vital role by providing health insurance and other insurance products for the poor".

According to Swiss Re (Sigma No.4/2000) "with the removal of entry barriers in emerging and less developed countries there has been an 
increased flow of funds from developed countries to the emerging and less developed countries. In recent years there has been a strong increase in the demand for insurance in the emerging markets. The average annual growth rate in the emerging markets has since 1990 been twice as high as industrial countries in both life and non-life insurance."

Jain, 2004 revealed, "Waves of liberalisation have done wonders to raise the insurance occupation to the status of a career with a bright future. The average mindset, particularly of younger generation in India is very amenable to these changes in insurance, which is as an avenue where exhilarating opportunities are opened up in changed environment". Sukla, 2006 reviewed, "the euphoria is well earned and the economic measures of liberalization initiated in insurance sector are well looked at. Six years into competitive market, the Indian insurance industry exhibited a healthy growth trend of new business and market share." Rao, 2007 reported, "Insurance is a vital economic activity and there is an excellent scope for its growth in the emerging markets. The opening up of the insurance sector has raised high hopes among people both in India and abroad. The recent detarrification in the non-life domain has provided a great deal of operational freedom to the players".

Sabera, 2007 indicated, "The Government of India liberalised the insurance sector in March 2000, which lifted the entry restrictions for private insurance players, allowing foreign players to enter into the market and start their operations in India. The entry of private players helps in spreading and keeping the operation in the Indian insurance sector which in turn results in restructuring and revitalising of public sector companies".

Krishnamurthy, 2007 pointed out that, the country is witnessing growing insurance awareness with such new generation products making entry, even in Tier 2 and Tier 3 cities. Private insurers have already made an impressive beginning. Liberalization has led to a new distribution channel, Bancassurance, a concept that is already firmly rooted in European countries. Sheele \& Arti, 2007 studied that the Indian market -both the urban and the rural offers tremendous growth opportunities for insurance companies, the need of the hour is to understand the changing needs of customers and their occupational structure. Chakraborty, 2007 examined that the Indian insurance industry underwent a drastic transformation with the entry of private players who captured a significant market share (26.6\%) during 2005-06.

Rajendran and Natarajan, 2010 were found that the business in India and the business outside India as well as the total businesses of LIC are always in an increasing trend. The collected and analysed data prove that the LPG is incorporating a positive influence on LIC of India and its performance. This paper is a further attempt to study the growth and performance of Life 
Insurance sector of the country and also tries to explore the opportunities and challenges that are face by the life insurance industry of the country.

\section{Insurance Sector - Status and Growth}

After privatisation, insurance industry has performed significant growth in terms of premium collection and extending business network. Due to low penetration and huge potential, many foreign and domestic players have entered in this sector. Moreover, several reform and policy measures have provided a favourable environment for insurance companies to flourish in the country.

The insurance sector in India is primarily divided into life and non-life, apart from a very small segment comprising re-insurance. Both the life and non-life insurance segments, which were nationalized in the 1950s and 1960s, respectively, witnessed an across-the-board liberalization process in 2000. After the reforms, the number of players has increased from one in life insurance and four in non-life insurance in 2000 to 23 players in life insurance sector \& 24 in non-life segment till Sept. 2010 (Table 1). It is observed from the literature that the reasons for the strong foundation for insurance services in India are: growing middle class segment, rising incomes, increasing awareness of insurance, as well as investments and infrastructure spending.

\section{Life Insurance Penetration and Insurance Density in India}

Strong economic growth of India has led to increased penetration of insurance in the country. Premium income as a percentage of GDP has increased from 3.3 percent in FY03 to 7.6 percent in FY09. However, the penetration level is still low as compared to other developed and developing economies. Many foreign companies have shown an interest in investing in Indian insurance companies, in spite of the FDI limit, which is fixed at 26 percent for the life and non-life sectors.

Life insurance penetration is taken as the total life insurance premium generated in a country as a percentage of GDP of that country. Table 3 indicates the life insurance penetration and insurance density in India and World. The penetration of life insurance in India is as 'still woefully low'. India had 16 percent of the world population, but only 1.68 percent of the world life insurance market in 2006. India is also far behind world averages in terms of insurance penetration and insurance density. A mere 20 percent of the insurable population aged 20 to 60 years is currently covered by life insurance. The average number of policies (life/non-life) held by per Indian consumer is just 1.33 as against 5.2 policies per consumer in mature markets (Capgemini World Insurance Report, 2008).

From Table 2, it is observed that the life insurance density in India is in increasing trend keeping the parity with International context. However, the 
non-life insurance density is very tardy and low density prevails in the country. The CAGR in the life insurance density in India is 19.20 percent while the non-life insurance is 10.57 percent (i.e. in 2002, the life insurance density in India was 11.7 USD while in 2009, it was 47.7 USD. Similarly, the non-life insurance density was 3.0 USD in 2002 which rose to 6.7 USD in 2009.). Further, the life insurance density in the world was 247.3 USD in 2002 which rose to 341.2 in 2009. Again, the non-life insurance density in the world was 175.6 USD in 2002 which rose to 253.9 USD in 2009.

Further, it is observed from Table 2, that the life insurance penetration in India is in decreasing trend keeping the parity with International context. However, the non-life insurance penetration is very tardy and low penetration prevails in the country. The CAGR in the life insurance penetration in India is 7.44 percent while the non-life insurance is $(-1.34 \%)$, i.e. in 2002 , the life insurance penetration in India was 2.59 percent while in 2009 it was $4.6 \%$. Similarly, the non-life insurance penetration was 0.67 percent in 2002 which declined to $0.60 \%$ in 2009). As a whole the life insurance industry penetration in India was 3.26 percent in 2002 which rose to 5.20 percent in 2009. The CAGR of insurance penetration is 6.01 percent. Further, the life insurance penetration in the world was 4.76 percent in 2002 which declined to four percent in 2009. Again, the non-life insurance penetration in the world was 3.38 percent in 2002 which declined to three percent in 2009. As a whole at present, the insurance density in India is 54.3 USD in 2009 while it is 595.1 USD in the world and the insurance penetration in India is 5.2 percent in 2009 while it is seven percent in the world.

\section{Growth in Total Insurance Premiums}

With several reforms and policy regulations, the Indian Insurance Sector has witnessed tremendous growth in the recent past. According to a report by the Associated Chambers of Commerce and Industry of India (ASSOCHAM), a growth of over 200 percent is likely to be seen in Indian insurance business by 2009-10, in which private insurance business would grow at 140 percent in view of aggressive marketing techniques (Pathak \& Tripathi, 2010). The projected growth rate is duly achieved which is reflected in different literature.

It is observed from Table 3 that LICI faces some trouble during the years of 2007-08 \& 2008-09 as they could not able to perform good business in terms of new business. On the other hand, the private players in the life insurance market though faces keen competition but able to maintain average increasing trend in respect to new policy issue. As a whole, the life insurance industry could not collect and maintain the aggressive business during the FY 08 and FY 09 which may responsible for financial crisis in the world economy and India's double digit inflation problem. Further, it is observed that the amount new business policy issued has increased at a CAGR of 5.36 percent in case LICI and negative growth rate of 2.02 percent in case of 
private players. But as a whole, the amount of new business policies issued increased in the insurance industry which increased at a CAGR of 9.26 percent.

Moreover, from Table 4, it is observed that the total premium earned by the insurance industry has grown at a CAGR of 22.49 percent ranging between Rupees 34898.47 crores (FY-01) to Rupees 265450.37 Crores (FY 2010). The total premium earned by the LIC has grown at a CAGR of 18.22 percent from Rupees 34892.02 crores in 2000-01 to Rupees 186077.31 Crores in 2009-10. The total premium earned by the private players has grown at a CAGR of 156.46 percent from Rupees 6.45 crores in 2000-01 to Rupees 79373.06 crores in 2009-10. Further, it is observed that the growth in CAGR in case of private players is much higher than the growth in CAGR in case of LICI in terms of total insurance premium. However, the Life Insurance Council has projected 18 percent growth in Total Premium income for the life Insurance Industry in the financial year 2009-10 and this projection was accordingly achieved.

\section{Market share of Life Insurers}

Market share of all life insurance is depicted in below figures (Fig $2 \&$ Fig- 3) which are based on first premium. Further, market share is determined in terms of premium received by the companies. Premium further divided as first year premium, renewal premium and total premium. It is seen that ICICI Prudential, Bajaj Allianz and SBI Life hold almost 50 percent of the market in the private life insurance segment. Seeing the potential of the industry, many banks have also entered in the sector in a phased manner. It is further observed from the Table 5 that LICI was the sole agency providing life insurance business till 2000.

After the entry of private sector, the share of LICI is in decreasing trend. As on 2009-10, the market share of LICI is 70.1 percent while the private sector is 29.90 percent. Moreover, from Table 6, it is observed that the market share of unit linked policy business is much prominent among the private players, while non-unit linked business as a share of insurance market is very popular in case of LICI. However, it is evident that the customer's preference towards ULIPs in case of private players and non-ULPs in case of LICI is very high as against non-ULIPs of private players and ULIPs of LICI. Further, it is observed from the study that ULIPs are most favoured among the customer recently and perhaps may be increasing toward the trend of equality between ULIPs and Non-ULIPs in the coming years. 
FIGURE 2

Growing market (in \%) share of private life insurance players based first year premiums

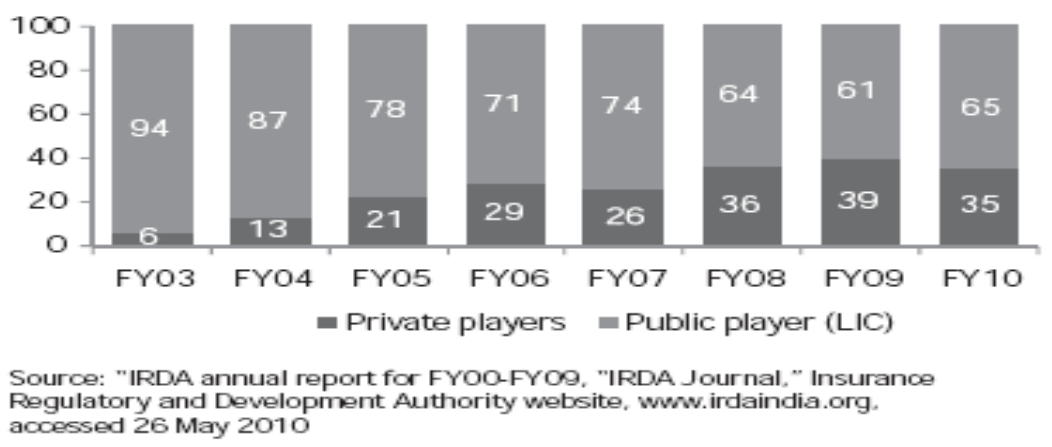

FIGURE 3

Market share amongst private players - FY10 (based on first year premiums) (in \%)
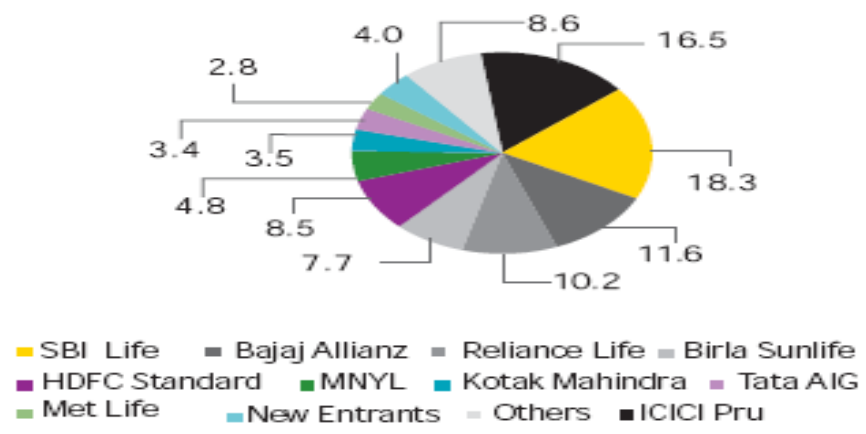

Source: "IRDA annual report FYO9, "IRDA Journal," Insurance Regulatory and Development Authority website, www. irdaindia.org. accessed 26 May 2010

\section{Profit and Loss of Life Insurers}

Data pertaining to profit and loss of insurance companies, both public and private, is tabulated in Table 7. It is amazing to note that all (15) private companies except two suffered losses ranging up to Rupees 1000 crore in the year 2006-07.It is further observed that all (22) private companies except Seven incurred losses during the FDY 2009-10. The accumulated losses (Table 8) of all private insurance companies in 2003-04 were Rupees 966.36 crore which further rose to Rupees 2049.52 crore in 2009-10 because of new entry of private players in to the industry. Table 9 depicts the amount of accumulated profit and losses of different private and public insurance companies. The CAGR of profit in case LICI is 9.79 percent, ranges from Rupees 551.81 crore in 2003-04 to Rupees 1060.72 crore in 2009-10. Further, it is observed that no private sector life insurance companies except Bajaz 
Alz earned profit of above Rupees 500 crore during the FY 2009-10 while LICI has earned profit of above Rupees 500 crores during the period 2003-04 to 2009-10. However, it is hopefully augmented that the entire sector turning profitable and it is expected to take another 2-3 years before almost all companies turn profitable. As of now, almost all private sector companies, barring a few, showed loss on their profit and loss account.

\section{Total premium, Commission Expenses and Operating Expenses}

It is observed from the Table 9 that total premium earned by LICI is in increasing trend. The CAGR of total premium in case of LICI is 16.59 percent ranges from Rupees 63533.43 crores in 2003-04 to Rupees 186077.31 crores in 2009-10, while the CAGR of total premiums in case of private players is $58.77 \%$, ranges from Rupees 3120.33 crores in 2003-04 to Rupees 79373.06 crores in 2009-10. Further, the commission expenses and operating expenses are also in the increasing trend. There is a direct relation between total premium and commission expenses. But operating expenses needs to be minimized for long term sustainability. The CAGR of operating expenses in case of LICI is 13.06 percent i.e. the volume of operating expenses for LICI in 2003-04 was Rupees 5186.49 crore which further roses to Rupees 12245.82 crores in 2009-10. Again, the CAGR of operating expenses in case of private players is 42.29 percent i.e. the volume of operating expenses for private players in 2003-04 was Rupees 1402.44 crore which further roses to Rupees 16561.11 crores in 2009-10. As a whole, the life insurance industry in India is suffering from high incremental rate of operating expenses. The CAGR of operating expenses in case of life insurance industry is $23.46 \%$, ranging from Rupees 6588.94 crores in 2003-04 to Rupees 28806.93 crores in 2009-10.

It is further observed that the percentage of operating expenses to total premium in case of LICI was 8.16 percent in 2003-04 which declined to 6.58 percent in 2009-10 and the percentage of operating expenses to total premium in case of private players in 2003-04 was 44.95 percent which further rose to 20.86 percent in 2009-10. As a whole, the percentage of operating expenses to total premium in case of insurance industry was 8.89 percent in 2003-04, which rose to 10.85 percent in 2009-10. Finally, it is observed that the percentage of operating expenses to total premium in both private and LICI is on decreasing trend.

\section{Opportunities for Growth}

1. It is estimated from the survey of literature that "aspirers" ['Aspirers'- Annual household income of Rupees 90,000 to Rupees 2 lakhs.] will comprise 46 percent of the population by 2012, representing a formidable emerging bankable class. Insurance is seen as long term savings instrument by this segment of the society providing higher return at low risk, given the lack of alternative 
investment options. Key challenges in this segment are managing profitability due to low ticket size and high underwriting risk.

2. After the recent financial crisis, insurance companies want to reduce their costs and outsourcing some of the non-core processes like claims processing, policy management etc, can help them to reduce their cost and focus on the core processes. India is seen as one of the favourable partners for the outsourcing business. Services such as analysis and decision support are likely to be the higher-end, billing rate-based services that will drive value growth for BPO organisations.

3. The health insurance sector is one of the booming sectors of the insurance industry as people are becoming more aware about the health care and their health insurance so taking advantage of this, private sector insurer's are more competitive in this segment. Life insurer companies are likely to primarily target the young population to amortize the risk over the policy term.

4. According to the Old Age Social and Income Security (OASIS Report, 1999), there will be 113 million Indian's over 60 years of age by 2016 and 179 million by 2026 . On the one hand, this is good news as the life expectancy has increased but on the other hand, it has also increased the risk that people will outlive their savings. Indians will have an expected life span of 80 years, i.e. live a full 20 non-earnings years. Health care costs have also increased many folds eroding retiree's purchasing power.

5. Social security provided by the Government of India is very limited; in fact that less than four percent of the population is covered under any social security scheme. Only Government employees are entitled to pension benefits after retirement. Opening up of the pension sector and the establishment of a new pension regulator have made this segment highly attractive. Hence, insurance products are being considered as the next best option to secure the future.

6. To facilitate insurance and social security cover for the economically weaker sections of society, the Pension Fund Regulatory \& Development Authority (PERDA) has launched a pension scheme, since April 2010, for rickshaw-pullers, barbers, daily wage earners etc. These social commitments on the part of the Government boost the growth of insurance market in India.

7. The transition from Solvency I to Solvency II norms by 2012 is likely to increase the demand for actuaries and risk management professional. The regulator has also asked insurance companies to get their risk management system and processes audited every three years by an external auditor to ensure the solvency of private sector companies. Hence, the need for professionals is expected to rise. Furthermore, insurance companies will now be able to calculate risk better, bringing enhanced stability in their operations and transparency in the sector. 


\section{Challenges before the Industry}

The four main challenges facing the insurance industry are product innovation, distribution, customer service, and investments. Unit-linked personal insurance products might find greater acceptability with rising customer awareness about customized, personalized and flexible products. Flexible products and new technology will play a crucial role in reducing the cost and, therefore, the price of insurance products. Finding niche markets, having the right product mix through add-on benefits and riders, effective branding of products and services and product differentiation will be some of the challenges faced by new companies.

New age companies have started their business with low product variety. Some of these companies have been able to float three or four products only and some have targeted to achieve the level of eight or ten products. At present, these companies are not in a position to pose any challenge to LIC and all other four companies operating in general insurance sector, but if we see the quality and standards of the products which they issued, they can certainly be a challenge in future. Because of some challenges in the entire environment caused by globalization and liberalization, the industry is facing the following challenges.

1. LIC may face problem of surrender of a large number of policies, as new insurers will encourage them by offering of innovative products at lower prices. Further, LIC have created a large group of dissatisfied customers due to the poor quality of service. There will be shift of large number of customers from LIC to the private insurers. Again, there is a likelihood of exit of young dynamic managers from LIC to the private insurer, as they will get higher package of remuneration.

2. Increased awareness and importance of insurance among public especially in urban areas compels more customized products and pricing methodology as per the needs of the customers. Further, customer expectations and awareness have significantly increased in recent years, particularly in terms of better and speedy service, accurate pricing and customized solutions. Therefore, how far LICI will comply with these requirements regarding innovative products is a matter of question.

3. LIC has overstaffing and with the introduction of full computerization, a large number of the employees will be surplus. However, they cannot be retrenched. The operating costs of LIC will not be reduced. This will be a disadvantage in the competitive market, as the new insurers will operate with lean office and high technology to reduce the operating costs.

4. Reaching the consumer expectations on par with foreign companies such as better yield and much improved quality of service particularly in the area of settlement of claims, issue of new policies, 
transfer of the policies and revival of policies in the liberalized market is very difficult to LIC and GIC.

5. Major challenges in canalizing the growth of insurance sector are product innovation, distribution network, investment management, customer service and education. Further, intense competition from new insurers in winning the consumers by multi-distribution channels, which will include agents, brokers, corporate intermediaries, bank branches, affinity groups and direct marketing through telesales and internet.

6. Both expense ratio and operating ratio is very high in the Indian insurance sector, especially for the private players. In FY 09, the private sector life insurance segment had an expense ratio (operating expenses \& commission expenses) of 30.6 percent. It is observed that the CAGR of operating expenses for LICI is $13.06 \%$ (03-04 to 9-10) while this is 42.29 percent for other private players (Table 9). Public sector companies have been in existence for a couple of decades and hence, have managed to reduce their expenses over time. However, experts on insurance field (Seth, 2005) believed that the expenses ratio should be around 10-15 percent from long term sustainability and profitability perspectives. A high expense ratio directly impacts profitability. Since the insurance industry is still at a nascent stage, many companies are yet to break down and rising expenses can further delay this process.

7. It is known fact that breakeven point is achieved in the insurance industry when the new business premium is equal to the renewal premium. As the Indian industry is growing, the volume of new premiums is much more than the renewal premiums (IRDA Annual Report, 2010). Globally, life insurance Company's break even is six to eight years but in India, it has not achieved \& it may take another couple of years due to recent financial crisis in the world. Other reasons for delayed breakeven are the high operating expenses like management costs, real estate prices, salaries, distribution expenses and technology expenses which are higher than what was accounted for in the original business plans of insurers. Moreover, the capital intensive nature of the life insurance segment has extended this process by a couple of years.

8. There are several important issues on which IRDA is working on. The convergence of the Indian Accounting Standards with the IFRS, the settlement of norms which will relate to the issuance of IPOs (initial public offers) and M\&As (mergers and acquisitions), the establishment of a more robust system to collect and disseminate appropriate insurance related data and several other initiatives are the main issues of global insurance. 


\section{CONCLUSIONS}

It is concluded from the observation and the analysis that life insurance sector in India has enlarged by more than twice after the formation of IRDA. It is also observed that LIC is losing its market share in favour of new entrants or private companies. While analyzing the data of various countries, a clear picture has emerged that developed countries have higher rate of insurance penetration whereas developing and under developed nations have relatively lesser rate of it. Being the largest insurance company in India, it is obvious that LIC has the largest strength of insurance agents and insurance business. It is further seen that LIC is well ahead of private insurers in terms of premium collection. It is worth noticing that all private companies suffered huge losses, but again, only LIC earned profits. It can be said that, LIC is the only life insurer in India that is fairly settled but the market share of LICI is decreasing day by day. Private players play a rivalry role in the insurance market. Further, it is observed that there should be a large gap between new business premium amount and renewal premium, but in case of Indian insurance business, this gap is too narrow. Moreover, the operating expenses of both private and public players are too high which needs to be minimized.

Over the past three years, around 40 companies have expressed interest in entering the sector and many foreign and Indian companies have arranged anticipatory alliances. The threat of new players taking over the market has been overplayed. As is witnessed in other countries where liberalization took place in recent years, we can safely conclude that nationalized players will continue to hold strong market share positions, but there will be enough business for entry to be profitable

Global integration of financial markets resulted from de-regulating measures, technological information explosion and financial innovations. Liberalisation and Globalization have allowed the entry of foreign players in the Insurance sector. With the entry of private and foreign players in the Insurance business, people have got a lot of options to choose from. Radical changes are taking place in customer profile due to the changing life style and social perception, resulting in erosion of brand loyalty. To survive, the focus of the modern insurers shifted to a customer-centric relationship.

Opening up the sector will certainly mean new products, better packaging and improved customer service. Both new and existing players will have to explore new distribution and marketing channels. Potential buyers for most of this insurance lie in the middle class. New insurers must segment the market carefully to arrive at appropriate products and pricing. Recognizing the potential, in the past three years, the nationalized insurers have already begun to target niches like pensions, women or children. 


\section{RECOMMENDATIONS AND SUGGESTIONS}

1. For the development of the life insurance sector, improvement in the insurance density and insurance penetration is a must. Hence, efforts need to be instituted for such improvement. Development of insurance products including special group policies to cater to different categories should be a priority, especially in rural areas.

2. The life insurers should conduct more extensive market research before introducing insurance products targeted at specific segments of the population so that insurance can become more meaningful and affordable.

3. Understanding the customer better will enable insurance companies to design appropriate products, determine price correctly and increase profitability.

4. Selection of right type of distribution channel mix along with prudent and efficient 'Fleet on Street' management. Ensurement of proper step for promotion of Banc assurance.

5. An efficient CRM system, which would eventually create sustainable competitive advantages and build a long-lasting relationship

6. Insurers must follow best investment practices and must have a strong asset management company to maximize returns.

7. Promoting health insurance and using e-broking to increase the business.

8. Consumer awareness campaign should be encouraged to improve financial literacy/ insurance literacy levels by conducting workshops, distributing leaflets, distributing literature etc. in both urban and rural areas. 


\section{REFERENCES}

Annual Reports of LICI and IRDA, different years from 2003 to 2010.

Business Standard, 29th September, 2010

Chakraborty, J. (2007). Private Life Insurance Companies in India: Growing Prospects and Challenges. Insurance Chronicle, the ICFAI University Press, VII (VIII): 29.

Jain, A.K. (2004). Journal of Insurance Institution. India, 30: 53.

Krishnamoorthi, (2007). A Study on Investors' Satisfaction with Special Reference to the Nilgiris District. Organizational Management, XXII (4):p. 9.

Krishnamurthy, (2007). Life Insurance: Less Rigid Norms May Help. The Hindu, Survey of Indian Industry.

Pathak, S. \& Tripathi V. (2010). Sales Force Turnover: An Exploratory Study of the Indian Insurance Sector. Management 5 (1): p.3.

Peter, D. (1999). Innovate or Die. Economist, 1(2): 41.

Rajendran, R. and Natarajan, B. (2010). The impact of liberalization, privatization, and globalization (LPG) on Life Insurance Corporation of India. African Journal of Business Management, 4(8), p.1457.

Rao, C.S. (2007). The Regulatory Challenges Ahead. Insurance Chronicle, 7: 10

Rao, T. (2000). The Indian Insurance Industry the Road Ahead. Insurance Chronicle, 3(I): 31.

Rastogi, S. \& Sarkar, R. (2008). Enhancing competiveness: The case of the Indian Life Insurance Industry. Available at web site of Indian Institute of Management, Kanpur.

Sabera, K.(2007). Changes in insurance sector (A Study on Public Awareness). Insurance Chronicle, 7(1): 37.

Seth, P. (2005). Insurance: Managing the coming boom amidst multiple challenges. Available at www.goggle.com

Sheela and Arti. (2007). A Study on the Awareness of Life Insurance Policies in Visakhapatnam. Insurance Chronicle. The ICFAI University Press, VII (IX):61.

Sukla, A.K. (2006). The impact of $L P G$ on life insurance. Journal of Insurance Institution. India, 32: 10.

Swiss Re (sigma No. 4/2000). Emerging Markets: The insurance industry in the face of globalization.

The Capgemini World Insurance Report of 2008. www.capgemini.com

The Economic Times, $19^{\text {th }}$ April. 2010 
TABLE 1

REGISTERED INSURERS IN INDIA

(As on $30^{\text {th }}$ September, 2010)

\begin{tabular}{|l|l|l|l|}
\hline Type of business & Public Sector & Private Sector & Total \\
\hline Life Insurance & 1 & 22 & 23 \\
\hline General Insurance & $6^{*}$ & $18^{* *}$ & 24 \\
\hline Reinsurance & 1 & 0 & 1 \\
\hline Total & 8 & 40 & 48 \\
\hline
\end{tabular}

Note: * Includes specialised insurance companies - ECGC and AIC

** Includes three Standalone Health Insurance Companies - Star Health \& Allied Insurance Co., Apollo Munich Health Insurance Co. and Max Bupa Health Insurance Co.; Includes L\&T General Insurance Company Ltd., which was granted registration in 2010-11.

TABLE 2

INSURANCE PENETRATION AND DENSITY IN INDIA AND WORLD

\begin{tabular}{|c|c|c|c|c|c|c|c|c|c|c|c|c|}
\hline Year & \multicolumn{4}{|c|}{ Life } & \multicolumn{4}{|c|}{ Non-Life } & \multicolumn{4}{|c|}{ Industry } \\
\hline & India & World & India & World & India & World & India & World & India & World & India & World \\
\hline & \multicolumn{2}{|c|}{ Density (USD) } & \multicolumn{2}{|c|}{ Penetration (\%) } & \multicolumn{2}{|c|}{ Density (USD) } & \multicolumn{2}{|c|}{ Penetration (\%) } & \multicolumn{2}{|c|}{ Density (USD) } & \multicolumn{2}{|c|}{ Penetration (\%) } \\
\hline 2002 & 11.7 & 247.3 & 2.59 & 4.76 & 3.0 & 175.6 & 0.67 & 3.38 & 14.7 & 422.9 & 3.26 & 8.14 \\
\hline 2003 & 12.9 & 267.1 & 2.26 & 4.59 & 3.5 & 202.5 & 0.62 & 3.48 & 16.4 & 469.6 & 2.88 & 8.06 \\
\hline 2004 & 15.7 & 291.5 & 2.53 & 4.55 & 4.0 & 220.0 & 0.64 & 3.43 & 19.7 & 511.5 & 3.17 & 7.99 \\
\hline 2005 & 18.3 & 299.5 & 2.53 & 4.34 & 4.4 & 219.0 & 0.61 & 3.18 & 22.7 & 518.5 & 3.14 & 7.52 \\
\hline 2006 & 33.2 & 330.6 & 4.10 & 4.50 & 5.2 & 224.2 & 0.60 & 3.00 & 38.4 & 554.8 & 4.80 & 7.50 \\
\hline 2007 & 40.4 & 358.1 & 4.00 & 4.40 & 6.2 & 249.6 & 0.60 & 3.10 & 46.6 & 607.7 & 4.70 & 7.50 \\
\hline 2008 & 41.2 & 369.7 & 4.00 & 4.10 & 6.2 & 264.2 & 0.60 & 2.90 & 47.4 & 633.9 & 4.60 & 7.10 \\
\hline 2009 & 47.7 & 341.2 & 4.60 & 4.00 & 6.7 & 253.9 & 0.60 & 3.00 & 54.3 & 595.1 & 5.20 & 7.00 \\
\hline
\end{tabular}

Source: Annual Report IRDA, 2009-10

Source: Swiss Re, Sigma; Annual Reports IRDA; * Data relates to financial year @ Insurance penetration is measured as ratio (in per cent) of premium (in US Dollars) to GDP (in US Dollars)

@ Insurance density is measured as ratio of premium (in US Dollars) to total population

TABLE 3

NEW POLICIES ISSUED: LIFE INSURERS (CRORE)

\begin{tabular}{|l|l|l|l|l|l|l|l|}
\hline Insurer & $\begin{array}{l}2003- \\
04\end{array}$ & $2004-05$ & $\begin{array}{l}2005- \\
06\end{array}$ & $2006-07$ & $\begin{array}{l}2007- \\
08\end{array}$ & $\begin{array}{l}2008- \\
09\end{array}$ & $\begin{array}{l}2009- \\
10\end{array}$ \\
\hline LICI & 2.69 & 2.39 & 3.15 & 3.82 & 3.76 & 3.59 & 3.88 \\
& & $(-11.09)$ & $(31.75)$ & $(21.01)$ & $(-1.61)$ & $(-4.52)$ & $(8.21)$ \\
\hline $\begin{array}{l}\text { Private } \\
\text { Sector }\end{array}$ & 1.65 & $\begin{array}{l}2.23 \\
(34.62)\end{array}$ & $\begin{array}{l}3.87 \\
(73.36)\end{array}$ & $\begin{array}{l}7.92 \\
(104.64)\end{array}$ & $\begin{array}{l}1.32 \\
(-\end{array}$ & $\begin{array}{l}1.50 \\
(13.19)\end{array}$ & $\begin{array}{l}1.43 \\
(-4.32)\end{array}$ \\
\hline Total & 2.86 & 2.62 & 3.54 & 4.16 & $\begin{array}{l}5.08 \\
(22.14)\end{array}$ & $\begin{array}{l}5.09 \\
(0.10)\end{array}$ & $\begin{array}{l}5.32 \\
(4.52)\end{array}$ \\
\hline
\end{tabular}

Data: Fig in brackets indicates growth over previous year (in \%)

Source: Annual Report IRDA 
TABLE 4

TOTAL LIFE INSURANCE PREMIUM ((RUPEES IN CRORE)

\begin{tabular}{|l|l|l|l|l|l|l|}
\hline Insurer & $\mathbf{2 0 0 0 - 0 1}$ & $\mathbf{2 0 0 1 - 0 2}$ & $\mathbf{2 0 0 2 - 0 3}$ & $\mathbf{2 0 0 3 - 0 4}$ & $\mathbf{2 0 0 4 - 0 5}$ & $\mathbf{2 0 0 5 - 0 6}$ \\
\hline LICI & 34892.02 & $\begin{array}{l}49821.91 \\
(42.79)\end{array}$ & $\begin{array}{l}54628.49 \\
(9.65)\end{array}$ & $\begin{array}{l}63533.43 \\
(16.30)\end{array}$ & $\begin{array}{l}75127.29 \\
(18.25)\end{array}$ & $\begin{array}{l}90792.22 \\
(20.85)\end{array}$ \\
\hline $\begin{array}{l}\text { Private } \\
\text { Total }\end{array}$ & 6.45 & $\begin{array}{l}272.55 \\
(4124.31)\end{array}$ & $\begin{array}{l}1119.06 \\
(310.59)\end{array}$ & $\begin{array}{l}3120.33 \\
(178.83)\end{array}$ & $\begin{array}{l}7727.51 \\
(147.65)\end{array}$ & $\begin{array}{l}15083.54 \\
(95.19)\end{array}$ \\
\hline $\begin{array}{l}\text { Industry } \\
\text { Total }\end{array}$ & 34898.47 & $\begin{array}{l}50094.46 \\
(43.54)\end{array}$ & $\begin{array}{l}55747.55 \\
(11.28)\end{array}$ & $\begin{array}{l}66653.75 \\
(19.56)\end{array}$ & $\begin{array}{l}82854.80 \\
(24.31)\end{array}$ & $\begin{array}{l}105875.76 \\
(27.78)\end{array}$ \\
\hline
\end{tabular}

TABLE 4 (cont.)

\begin{tabular}{|l|l|l|l|l|}
\hline Insurer & $\mathbf{2 0 0 6 - 0 7}$ & $\mathbf{2 0 0 7 - 0 8}$ & $\mathbf{2 0 0 8 - 0 9}$ & $\mathbf{2 0 0 9 - 1 0}$ \\
\hline \multirow{2}{*}{ LICI } & $\begin{array}{l}\text { 127822.84 } \\
(40.79)\end{array}$ & $\begin{array}{l}149789.99 \\
(17.19)\end{array}$ & $\begin{array}{l}157288.04 \\
(5.01)\end{array}$ & $\begin{array}{l}186077.31 \\
(18.30)\end{array}$ \\
\hline \multirow{2}{*}{ Private Total } & $\begin{array}{l}28242.48 \\
(87.24)\end{array}$ & $\begin{array}{l}51561.42 \\
(82.57)\end{array}$ & $\begin{array}{l}64497.43 \\
(25.09)\end{array}$ & $\begin{array}{l}79373.06 \\
(23.06)\end{array}$ \\
\hline \multirow{2}{*}{ Industry Total } & $\begin{array}{l}156065.32 \\
(47.38)\end{array}$ & $\begin{array}{l}201351.41 \\
(29.01)\end{array}$ & $\begin{array}{l}221785.47 \\
(10.15)\end{array}$ & $\begin{array}{l}265450.37 \\
(19.69)\end{array}$ \\
\hline
\end{tabular}

Source: Annual Report IRDA. (Fig in brackets represents the growth over the previous year)

TABLE 5

MARKET SHARE OF LIFE INSURER (\%)

\begin{tabular}{|c|c|c|}
\hline YEAR & LICI & PRIVATE SECTOR \\
\hline $1999-00$ & 100 & 0 \\
\hline $2000-01$ & 99.98 & 0.02 \\
\hline $2001-02$ & 99.46 & 0.54 \\
\hline $2002-03$ & 97.99 & 2.01 \\
\hline $2003-04$ & 95.32 & 4.68 \\
\hline $2004-05$ & 90.67 & 9.33 \\
\hline $2005-06$ & 85.75 & 14.25 \\
\hline $2006-07$ & 81.90 & 18.10 \\
\hline $2007-08$ & 74.39 & 25.61 \\
\hline $2008-09$ & 70.92 & 29.08 \\
\hline $2009-10$ & 70.10 & 29.90 \\
\hline
\end{tabular}

Source: IRDA Annual Report

TABLE 6

TRENDS IN LIFE INSURANCE BUSINESS: UNIT LINKED INSURANCE PLANS

\begin{tabular}{|l|c|c|c|c|c|c|c|c|c|c|}
\hline Insurer & \multicolumn{4}{|c|}{ Unit Linked Business (\%) } & \multicolumn{4}{c|}{ Non-unit Linked Business (\%) } \\
\hline & $\begin{array}{c}\mathbf{2 0 0 5 -} \\
\mathbf{0 6}\end{array}$ & $\begin{array}{c}\mathbf{2 0 0 6 -} \\
\mathbf{0 7}\end{array}$ & $\begin{array}{c}\mathbf{2 0 0 7 -} \\
\mathbf{0 8}\end{array}$ & $\begin{array}{c}\mathbf{2 0 0 8 -} \\
\mathbf{0 9}\end{array}$ & $\begin{array}{c}\mathbf{2 0 0 9 -} \\
\mathbf{1 0}\end{array}$ & $\begin{array}{c}\mathbf{2 0 0 5 -} \\
\mathbf{0 6}\end{array}$ & $\begin{array}{c}\mathbf{2 0 0 6 -} \\
\mathbf{0 7}\end{array}$ & $\begin{array}{c}\mathbf{2 0 0 7 -} \\
\mathbf{0 8}\end{array}$ & $\begin{array}{c}\mathbf{2 0 0 8 -} \\
\mathbf{0 9}\end{array}$ & $\begin{array}{c}\mathbf{2 0 0 9 -} \\
\mathbf{1 0}\end{array}$ \\
\hline Private & 82.30 & 88.75 & 90.33 & 86.75 & 86.00 & 17.70 & 11.25 & 9.67 & 13.25 & 14.00 \\
\hline LICI & 29.76 & 46.31 & 62.31 & 22.06 & 25.4 & 70.24 & 53.69 & 37.69 & 77.94 & 74.60 \\
\hline $\begin{array}{l}\text { Industry } \\
\text { Total }\end{array}$ & 41.77 & 56.91 & 70.30 & 40.87 & 43.52 & 58.23 & 43.09 & 29.70 & 59.13 & 56.48 \\
\hline
\end{tabular}

Data: Percentage share of ULIP Premium out of Total Premium.

Source: Annual Report, IRDA 2007-08, IRDA 2009-10 and other 
TABLE 7

NUMBER OF LIFE INSURANCE COMPANIES ACCORDING TO PROFIT RANGE

\begin{tabular}{|c|c|c|c|c|c|c|c|c|}
\hline \multirow{2}{*}{$\begin{array}{c}\text { Profit/Loss } \\
\text { Range } \\
\text { (Rupees in } \\
\text { Crore) } \\
\end{array}$} & \multicolumn{2}{|c|}{ 2003-04 } & \multicolumn{2}{|c|}{ 2004-05 } & \multicolumn{2}{|c|}{ 2005-06 } & \multicolumn{2}{|c|}{ 2006-07 } \\
\hline & $\begin{array}{l}\text { Public } \\
\text { Sector }\end{array}$ & $\begin{array}{l}\text { Private } \\
\text { Sector }\end{array}$ & $\begin{array}{l}\text { Public } \\
\text { Sector }\end{array}$ & $\begin{array}{l}\text { Private } \\
\text { Sector }\end{array}$ & $\begin{array}{l}\text { Public } \\
\text { Sector }\end{array}$ & $\begin{array}{l}\text { Private } \\
\text { Sector }\end{array}$ & $\begin{array}{l}\text { Public } \\
\text { Sector }\end{array}$ & $\begin{array}{l}\text { Private } \\
\text { Sector }\end{array}$ \\
\hline \multicolumn{9}{|l|}{ Loss } \\
\hline$>1000$ & - & - & - & - & - & - & - & - \\
\hline $\begin{array}{l}500- \\
1000\end{array}$ & - & - & - & - & - & - & - & 1 \\
\hline $400-500$ & - & - & - & - & - & - & - & - \\
\hline $300-400$ & - & - & - & - & - & - & - & 1 \\
\hline $200-300$ & - & 2 & - & 1 & - & - & - & - \\
\hline $100-200$ & - & - & - & - & - & 4 & - & 5 \\
\hline $0-100$ & - & 10 & - & 12 & - & 8 & - & 6 \\
\hline \multicolumn{9}{|l|}{ Profit } \\
\hline $0-100$ & - & - & - & - & - & 2 & - & 2 \\
\hline $100-200$ & - & - & - & - & - & - & - & - \\
\hline $200-300$ & - & - & - & - & - & - & - & - \\
\hline $300--500$ & - & - & - & - & - & - & - & - \\
\hline$>500$ & 1 & - & 1 & - & 1 & - & 1 & - \\
\hline Total & 1 & 12 & 1 & 13 & 1 & 14 & 1 & 15 \\
\hline
\end{tabular}

Source: IRDA Annual Report

TABLE 7 (Cont.)

\begin{tabular}{|c|c|c|c|c|c|c|}
\hline \multirow{2}{*}{$\begin{array}{l}\text { Profit/Loss } \\
\text { Range (Rupees in } \\
\text { Crore) }\end{array}$} & \multicolumn{2}{|c|}{ 2007-08 } & \multicolumn{2}{|c|}{ 2008-09 } & \multicolumn{2}{|c|}{$2009-10$} \\
\hline & $\begin{array}{l}\text { Public } \\
\text { Sector }\end{array}$ & $\begin{array}{r}\text { Private } \\
\text { Sector }\end{array}$ & $\begin{array}{l}\text { Public } \\
\text { Sector }\end{array}$ & $\begin{array}{l}\text { Private } \\
\text { Sector }\end{array}$ & $\begin{array}{l}\text { Public } \\
\text { Sector }\end{array}$ & $\begin{array}{r}\text { Private } \\
\text { Sector }\end{array}$ \\
\hline \multicolumn{7}{|l|}{ Loss } \\
\hline$>1000$ & - & 1 & - & 1 & - & - \\
\hline $500-1000$ & - & 1 & - & 4 & - & - \\
\hline $400-500$ & - & 1 & - & 2 & - & 3 \\
\hline $300-400$ & - & 1 & - & 1 & - & 2 \\
\hline $200-300$ & - & 4 & - & 2 & - & 3 \\
\hline $100-200$ & - & 2 & - & 2 & - & 2 \\
\hline $0-100$ & - & 3 & - & 5 & - & 5 \\
\hline \multicolumn{7}{|l|}{ Profit } \\
\hline $0-100$ & - & 4 & - & 4 & - & 4 \\
\hline $100-200$ & - & - & - & - & - & - \\
\hline $200-300$ & - & - & - & - & - & 2 \\
\hline $300--500$ & - & - & - & - & - & - \\
\hline$>500$ & 1 & - & 1 & - & 1 & 1 \\
\hline Total & 1 & 17 & 1 & 21 & 1 & 22 \\
\hline
\end{tabular}

Data: Profit/Loss indicates profit after tax only; Source: Annual Reports IRDA 
TABLE 8

NET PROFIT/LOSS AFTER TAX OF LIFE INSURER (RUPEES IN CRORE)

\begin{tabular}{|l|l|l|l|l|l|l|l|}
\hline Insurer & $\begin{array}{l}2003- \\
04\end{array}$ & $\begin{array}{l}2004- \\
05\end{array}$ & $2005-06$ & $\begin{array}{l}2006- \\
07\end{array}$ & $\begin{array}{l}2007- \\
08\end{array}$ & $\begin{array}{l}2008- \\
09\end{array}$ & $2009-10$ \\
\hline $\begin{array}{l}\text { Private } \\
\text { insurance }\end{array}$ & 966.36 & 869.18 & 91647.88 & 1936.79 & 4259.97 & 4710.98 & 2049.52 \\
\hline LICI & +551.81 & +708.37 & +631.58 & +773.62 & +844.63 & +957.35 & +1060.72 \\
\hline $\begin{array}{l}\text { Industry } \\
\text { Total }\end{array}$ & 414.56 & 164.83 & 470.90 & 1159.60 & 3412.81 & 4883.01 & 988.82 \\
\hline
\end{tabular}

Source: Annual Report IRDA

TABLE 9

TOTAL PREMIUM, COMMISSION EXPENSES AND OPERATING EXPENSES: LIFE INSURERS (RUPEES IN CRORE)

\begin{tabular}{|c|c|c|c|c|c|c|}
\hline Year & \multicolumn{3}{|c|}{ Total Premium } & \multicolumn{3}{c|}{ Commission Expenses } \\
\hline & LICI & $\begin{array}{c}\text { Pvt. } \\
\text { Sector }\end{array}$ & Total & LICI & $\begin{array}{c}\text { Pvt. } \\
\text { Sector }\end{array}$ & Total \\
\hline $2003-04$ & 63533.43 & 3120.33 & 66653.75 & 5742.91 & 415.42 & 6158.33 \\
\hline $2004-05$ & 75127.29 & 7727.51 & 82854.8 & 6203.23 & 854.73 & 7057.96 \\
\hline $2005-06$ & 90792.22 & 15083.54 & 105875.76 & 7100.19 & 1543.1 & 8643.29 \\
\hline $2006-07$ & 127822.84 & 28242.48 & 156065.32 & 9173.58 & 3085.4 & 12258.98 \\
\hline $2007-08$ & 149789.99 & 51561.42 & 201351.41 & 9614.69 & 5089.61 & 14704.3 \\
\hline $2008-09$ & 157288.04 & 64497.43 & 221785.47 & 10055.09 & 5474.27 & 15529.36 \\
\hline $2009-10$ & 186077.31 & 79373.06 & 265450.37 & 12132.56 & 6052.75 & 18185.31 \\
\hline
\end{tabular}

Source: complied, Data: Figure in brackets indicates growth over previous year (in \%)

TABLE 9 (CONT.)

\begin{tabular}{|r|l|l|l|r|r|r|}
\hline YEAR & \multirow{2}{*}{ Operating Expenses } & & \multicolumn{3}{|c|}{ PC OF OE TO TP } \\
\hline & LICI & $\begin{array}{l}\text { Private } \\
\text { Sector }\end{array}$ & Total & \multicolumn{1}{|c|}{ LIC } & \multicolumn{1}{|c|}{ Pvt. } & \multicolumn{1}{|c|}{ Total } \\
\hline $2003-04$ & 5186.49 & 1402.44 & 6588.94 & 8.16 & 44.95 & 9.89 \\
\hline $2004-05$ & 6241.26 & 2229.47 & 8470.47 & 8.31 & 28.85 & 10.22 \\
\hline $2005-06$ & 6041.56 & 3569.48 & 9611.04 & 6.65 & 23.66 & 9.08 \\
\hline $2006-07$ & 7085.84 & 6500.01 & 13585.85 & 5.54 & 23.02 & 8.71 \\
\hline $2007-08$ & 8309.32 & 11989.34 & 20298.66 & 5.55 & 23.25 & 10.08 \\
\hline $2008-09$ & 9064.29 & 16763.03 & 25827.32 & 5.76 & 25.99 & 11.65 \\
\hline $2009-10$ & 12245.82 & 16561.11 & 28806.93 & 6.58 & 20.86 & 10.85 \\
\hline
\end{tabular}

